\title{
THERMAL IMPACTS OF A COAL POWER PLANT ON THE PLANKTON IN AN OPEN COASTAL WATER ENVIRONMENT
}

Keun-Hyung Choi

Korea Institute of Coastal Ecology, Inc., \#302-802 Ssangyong Technopark III 36-1 Samjeong-dong, Ojeong-gu, Bucheon-si, Gyeonggi-do 421-742, Korea, keunhchoi@gmail.com

Young-Ok Kim

Southern Coastal Environment Research Department, South Sea Institute, Korea Ocean Research \& Development Institute, Jangmok-myeon, Geoje-si, Gyungnam-do 656-830, Korea

Joon-Baek Lee

Department of Earth and Marine Sciences, Jeju National University, 1, Ara 1-dong, 102 Jejudaehakno, Jeju-si, Jeju Special Self-Governing Province 690-756, Korea

Soon-Young Wang ARA Consulting and Technology, 303, Dae-Han Bldg., 708-7, Songnae-dong, Sosa-gu, Bucheon-si, Gyeonggi-do, Korea

Man-Woo Lee

Korea Institute of Coastal Ecology, Inc., \#302-802 Ssangyong Technopark III 36-1 Samjeong-dong, Ojeong-gu, Bucheon-si, Gyeonggi-do 421-742, Korea

See next page for additional authors

Follow this and additional works at: https://jmstt.ntou.edu.tw/journal

Part of the Marine Biology Commons

\footnotetext{
Recommended Citation

Choi, Keun-Hyung; Kim, Young-Ok; Lee, Joon-Baek; Wang, Soon-Young; Lee, Man-Woo; Lee, Pyung-Gang; Ahn, DongSik; Hong, Jae-Sang; and Soh, Ho-Young (2012) "THERMAL IMPACTS OF A COAL POWER PLANT ON THE PLANKTON IN AN OPEN COASTAL WATER ENVIRONMENT," Journal of Marine Science and Technology. Vol. 20: Iss. 2, Article 9. DOI: 10.51400/2709-6998.1837

Available at: https://jmstt.ntou.edu.tw/journal/vol20/iss2/9

This Research Article is brought to you for free and open access by Journal of Marine Science and Technology. It has been accepted for inclusion in Journal of Marine Science and Technology by an authorized editor of Journal of Marine Science and Technology.
} 


\section{THERMAL IMPACTS OF A COAL POWER PLANT ON THE PLANKTON IN AN}

OPEN COASTAL WATER ENVIRONMENT

\section{Acknowledgements}

This research was funded by the Korea South-East Power Co.'s project "Post-environmental impact assessment of YoungHeung Power Plant". We thank Young-Soo Park at KSEP for assistance with the project, and Min-Ho Soh for his assistance with laboratory work for zooplankton samples. We also thank two anonymous reviewers for their helpful comments on an earlier version of this manuscript.

\section{Authors}

Keun-Hyung Choi, Young-Ok Kim, Joon-Baek Lee, Soon-Young Wang, Man-Woo Lee, Pyung-Gang Lee, Dong-Sik Ahn, Jae-Sang Hong, and Ho-Young Soh 


\title{
THERMAL IMPACTS OF A COAL POWER PLANT ON THE PLANKTON IN AN OPEN COASTAL WATER ENVIRONMENT
}

\author{
Keun-Hyung Choi ${ }^{1}$, Young-Ok Kim ${ }^{2}$, Joon-Baek Lee ${ }^{3}$, Soon-Young Wang ${ }^{4}$, Man-Woo Lee ${ }^{1}$, \\ Pyung-Gang Lee ${ }^{5}$, Dong-Sik Ahn ${ }^{1}$, Jae-Sang Hong ${ }^{6}$, and Ho-Young Soh ${ }^{7}$
}

Key words: thermal effluents, copepod, mortality, coastal waters.

\begin{abstract}
Over a five-year period, this study examined the overall impact of coal power plant cooling processes on entrained copepods and the local plankton community on the west coast of Korea. Mortality differences between the intake and discharge water of the single most dominant copepod, Acartia hongi, were positively correlated with temperature differences between the two locations. Laboratory tests showed copepod sensitivity to temperature increase, and with very low chlorine concentration applied, thermal stress was the major source of copepod mortality. Chlorophyll a concentration, ciliate abundance, and total copepod abundance at the intake showed no discernable differences from the values at the discharge. Most likely, this was due to rapid mixing of the population in the discharge water with adjacent populations in the macrotidal open coastal water environment.
\end{abstract}

\section{INTRODUCTION}

Once-through cooling systems of coastal power plants can cause various adverse impacts on plankton communities, in-

Paper submitted 05/28/10; revised 10/12/10; accepted 12/14/10. Author for correspondence: Keun-Hyung Choi (e-mail: keunhchoi@gmail.com).

${ }^{1}$ Korea Institute of Coastal Ecology, Inc., \#302-802 Ssangyong Technopark III 36-1 Samjeong-dong, Ojeong-gu, Bucheon-si, Gyeonggi-do 421-742, Korea. ${ }^{2}$ Southern Coastal Environment Research Department, South Sea Institute, Korea Ocean Research \& Development Institute, Jangmok-myeon, Geoje-si, Gyungnam-do 656-830, Korea.

${ }^{3}$ Department of Earth and Marine Sciences, Jeju National University, 1, Ara 1-dong, 102 Jejudaehakno, Jeju-si, Jeju Special Self-Governing Province 690-756, Korea.

${ }^{4}$ ARA Consulting and Technology, 303, Dae-Han Bldg., 708-7, Songnae-dong, Sosa-gu, Bucheon-si, Gyeonggi-do, Korea.

${ }^{5}$ Institute of Ecology \& Environment, Inc., Bupyeong2-dong Bupyeong-gu Incheon-si, 751-161, Korea.

${ }^{6}$ Department of Ocean Sciences, Inha University, Incheon 402-751, Korea.

${ }^{7}$ Division of Marine Technology, Chonnam National Univeristy San 96-1, Dundeog-dong, Yeosu, Jellanam-do 550-749, Korea. cluding decreased biomass and productivity of entrained heterotrophic bacteria and phytoplankton [4, 6, 26, 29, 30, 32], reduced survival of entrained zooplankton and other metazoans $[1,4,5,8,14,19]$ and reduced diversity of the zooplankton community [38].

The mechanisms by which cooling processes affect entrained plankton are rather complex. Previously, it was thought that much of the damage to the plankton community was caused by physical and mechanical stresses such as pressure changes and shear forces during condenser passage, and biocides (e.g. chlorine) applied to prevent fouling in the condenser. However, recent evidence emphasizes that thermal stress may be a major source of entrained plankton mortality $[23,35]$ and that most survival estimates determined in the absence of thermal effects were relatively high [23, 35]. With varying results depending on organisms and operational conditions [1, 3, 29], synergistic effects of multiple stresses, mostly temperature and residual chlorine, on the plankton community have been reported. Such variable impact results suggest the necessity for testing the ecological impact of the cooling process of each power plant.

The Young-Heung Coal Power Plant is situated on a reclaimed lot on the western tip of Young-Heung Island (hereafter YH Island) off the west coast of Korea. It is a four-unit power plant which produces 2200 megawatts at full operational capacity. Per each plant unit, the power plant draws between 71,000 and $125,000 \mathrm{~m}^{3}$ of coastal water each hour through its once-through cooling system. Given its relatively large volume of seawater draw and extensive amount of plankton extraction, a significant threat to the coastal ecosystems surrounding the power plant may be posed.

Monitoring studies have been implemented to investigate the extent to which plant operations affect the plankton community that passes through the condenser cooling systems. The studies are also intended to examine overall impacts on planktonic, benthic, macroalgal, and fish communities around the island, which consequently produce quite an extensive amount of data. This study presents the measurement results of copepod mortality at the intake and discharge. With a focus on $A$. hongi, the single most dominant planktonic copepod on 


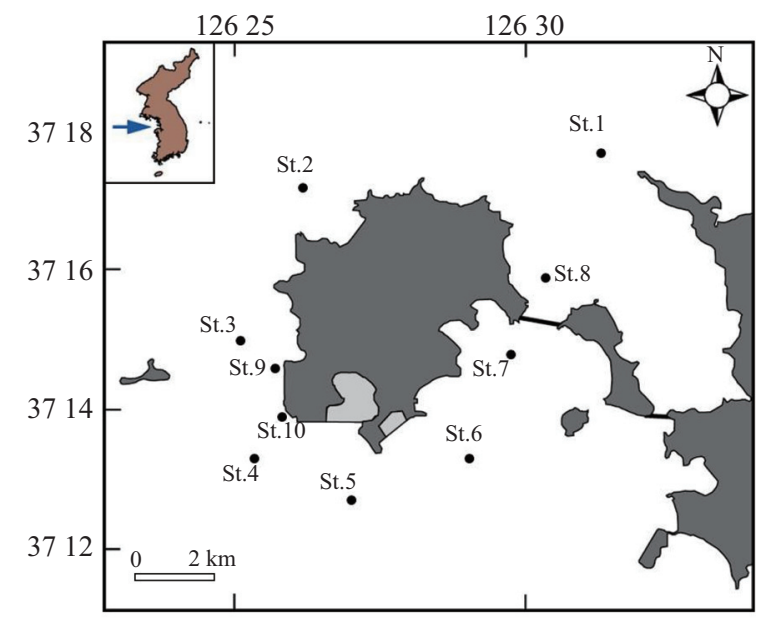

Fig. 1. Young-Heung coal power plant and sampling locations: Station 9intake, Station 10-discharge area.

the west coast of Korea, we also present experimental laboratory results testing thermal impacts on copepod survival and egg production rate. To examine regional scale impact of thermal discharge on plankton dynamics, a five-year survey of plankton biomass is also presented.

\section{MATERIAL AND METHOD}

The power plant is located on a reclaimed rectangular lot (Fig. 1), with the intake located at Station 9 and the discharge at Station 10, on Young-Heung Island off the west coast of Korea. With two more units under construction alongside the existing plants, four power plant units are currently operating. Cooling water is drawn into the plant from approximately 12 $\mathrm{m}$ beneath the surface through four intake inlets for each plant unit. Once the cooling water passes through the condenser, and before it is discharged through a subsurface discharge jet located at about the $7 \mathrm{~m}$ depth contour, the cooling water is fed into a small hydro to generate a small amount of electricity. At the seawater inlet intake pipe head, sodium hypochlorite, produced from electrolyzing seawater, is dosed continuously at nominal concentrations of $<0.1 \mathrm{ppm}$ to prevent biofilm growth on the surface of condenser tubes. It takes approximately 20 min. for the cooling water to travel between the dosing point and the outfall. Tidal current, with an average tidal amplitude of about $5.7 \mathrm{~m}$, is directed north-east and south-west such that heated seawater effluents flow out predominantly in the southwest direction during ebbs, with a part of the plume spreading toward Station 3 during floods. Water temperature at $1 \mathrm{~m}$ below the intake and discharge points was recorded every thirty minutes for a month with a Hydrocast (accuracy of $\pm 0.05^{\circ} \mathrm{C}$ ) during each sampling month to measure water temperature variation at both locations.

Live zooplankton sampling, for mortality assessment at both locations, was carried out at the intake and discharge sites on the same dates as other samplings in 2008 and 2009. Zoo- plankton sampling was carried out by obliquely hauling slowly at the intake. Sampling was also conducted at a location $30 \mathrm{~m}$ off the discharge point of the effluents, as the discharge point was fenced around with meshed wire. Equipped with a flowmeter and a meshed cod end bucket, a $45-\mathrm{cm}$ mouth diameter, $200-\mu \mathrm{m}$ mesh net was used. Staining experiments using neutral red were carried out immediately after each sampling with some modifications to differentiate live from dead copepods $[7,9,33]$. Collected zooplankton were carefully transferred to a beaker onboard and a stock stain solution $(2 \% \mathrm{~W} / \mathrm{V}$ in distilled water) was added to the seawater in the beaker, yielding a final concentration of 1:150,000. Each complete sample was placed in a warm water bath for $15 \mathrm{~min}$, sieved gently through a $200-\mu \mathrm{m}$ mesh, and preserved in $500 \mathrm{ml}$ of $2 \%$ of alkaline formalin with $\mathrm{NaOH}(p \mathrm{H}=9)$. In the laboratory, and within two days of sampling, preserved samples were acidified with diluted acetic acid prior to microscopic examination. Mortality was documented for individuals of two major calanoid copepod species present in the samples, which included Acartia hong $i$ adults and $A$. hongi copepodites for all sampling times, and Paracalanus parvus adults in August and October when species abundance was sufficient for reliable estimation.

Laboratory experiments were conducted to assess the thermal shock effects on the survival and egg production rate of $A$. hongi adults. In May and November 2009, copepods were gently collected at a pier of the power plant by vertical tow net, transferred into a vinyl bag with added liquefied oxygen, and transported to the laboratory. Copepods were diluted into $5 \mathrm{~L}$ aquariums, fed twice a day with a mixed culture of Nannochloropsis oculata and Isochrisis galbana, and maintained at $15^{\circ} \mathrm{C}$. To achieve desired water temperature $\left(12^{\circ} \mathrm{C}\right.$ for the copepods collected in May, and 20 and $23^{\circ} \mathrm{C}$ for November samples), water temperature of the $5 \mathrm{~L}$ aquariums was incremented or decremented by $1^{\circ} \mathrm{C}$ per day. Temperature of experimental seawater beakers (1L) was adjusted with the same technique, with a submersible aquarium heater used to maintain water temperature. For each temperature treatment, twenty healthy copepods were transferred into each of the $1 \mathrm{~L}$ beakers in triplicate, and incubated for $72 \mathrm{~h}$, with $80 \%$ of the water in the beakers replaced daily with fresh seawater of the same temperature and salinity. Copepods were checked each day and the dead were removed from the beakers. All sea-water used for the experiments was autoclaved for $15 \mathrm{~min}$. at $120 \mathrm{psi}$ and filtered through a GF/F filter with aeration prior to the experiments. Salinity was maintained at 30 in all experiments.

Temperature effect experiments on the egg production rate of $A$. hong $i$ were set up in the same manner as for the mortality tests, except that temperature experiments were conducted in February and May. Twenty healthy females were placed in each of $1 \mathrm{~L}$ beakers in triplicate and incubated for $24 \mathrm{~h}$. The females were checked for life, and egg production rate was adjusted according to the number of females that survived during the incubation. From late 2004 to 2009, plankton samples were collected quarterly in each year (generally in February, May, August, and October), twice in each sampling month at 


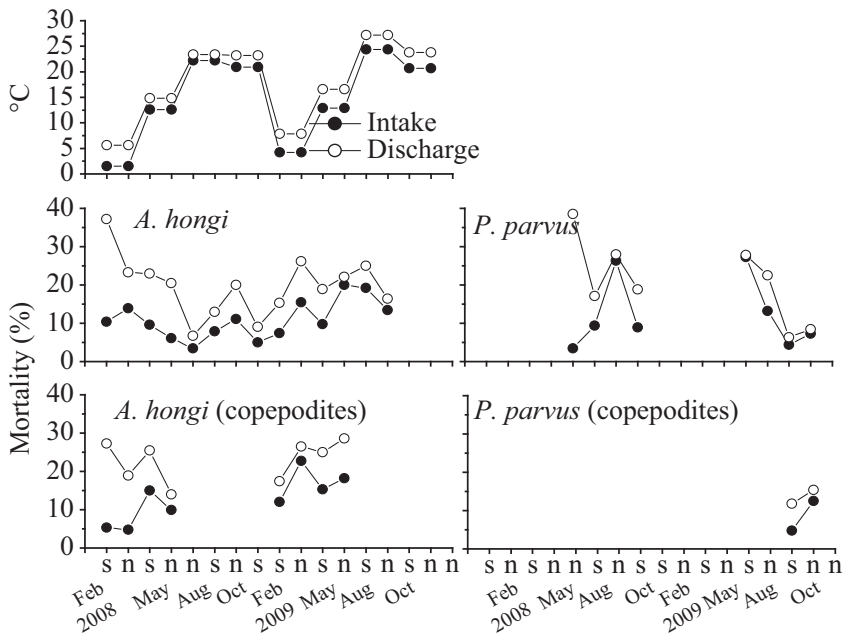

Fig. 2. Percent of dead copepods as measured with vital staining of copepods collected from both seawater intake (Station 9) and discharge (Station 10). $\mathrm{n}$ - neap tide, $\mathrm{s}$ - spring tide.

neap and the following spring tides or vice versa, with time gaps of $<10$ days between collections. In addition to the intake and discharge waters, sampling covered eight additional stations around YH Island. As measured by chlorophyll $a$ (chl $a$ ) concentration and ciliates, all water samples for phytoplankton biomass, were collected at both the surface and bottom of the water column. Water samples for chl $a$ were filtered onto $47 \mathrm{~mm} \mathrm{GF/F} \mathrm{filters} \mathrm{onboard,} \mathrm{chilled} \mathrm{on} \mathrm{icepacks,}$ transported to the laboratory, and placed in $90 \%$ acetone overnight to extract chl $a$. The chl $a$ concentration was measured later by fluorometric determination [28]. Water samples for ciliates were preserved in Lugol's solution (final concentration of 1\%), allowed to settle in $50 \mathrm{ml}$ Utermõhl chambers, and examined with inverted microscopy at 100 or $200 \mathrm{X}$. The concentration differences between the surface and bottom waters for chl $a$ and ciliates were small, averaging $16.5 \%$ and $24.5 \%$, respectively. Thus, average values of surface and bottom waters were used for further analyses. Zooplankton samples collected at the ten sampling sites (Fig. 1), were preserved in $4 \%$ buffered formalin onboard. In the laboratory, subsampling was conducted and zooplankton were examined in a grooved counting tray under a stereozoom dissecting microscope and identified to the lowest taxon as possible.

\section{RESULTS}

\section{Water Temperature}

Intake water temperature measured at the monitoring site varies seasonally, from about $2^{\circ} \mathrm{C}$ to $27^{\circ} \mathrm{C}$, with similar seasonal cycles between 2008 and 2009 (Fig. 2). Discharge point temperature (Fig. 2) varies similarly by season as intake temperature but, regardless of the month monitored, is $<3-4{ }^{\circ} \mathrm{C}$ higher on average than at the intake. Summer discharge water temperature approaches $27^{\circ} \mathrm{C}$, but never exceeds $30^{\circ} \mathrm{C}$.

\section{Mortality of Copepods in the Field}

Mortality of the A. hongi field populations at the intake was measured with a neutral-red staining and varies from 3 to $19 \%$ with an average of about $10 \%$, whereas mortality varies from 7 to $37 \%$ at the discharge, with an average of about $20 \%$. Intake mortality is not correlated with seasonality in water temperature (a linear regression, $p=0.73$ ). Although discharge mortality tends to decrease with a rise in the discharge water temperature, it is not significant $(p=0.06)$. A. hongi copepodites also show a similar temporal trend to that of the adults, with an average mortality of 13 and $23 \%$ at the intake and discharge, respectively. It also appears there is no difference in mortality between the sampling times of neap and spring tide in each season (Fig. 2). The summer copepod P. parvus, for which mortality was measured only in summer and fall when abundance was high enough for reliable estimation, displays a somewhat narrower range of mortality than A. hongi, with average mortality of 13 and $21 \%$ at the intake and discharge, respectively.

In general, mortality tests in discharge water for both copepod species and life stage closely follow the mortality trend in the intake with a few exceptions, most notably at spring tide in February 2008 when the mortality at the discharge was the highest surveyed. Mortality differences between the intake and discharge are similar across the species and life stages tested, $8.9 \%$ for $A$. hongi adults, $10.0 \%$ for $A$. hongi copepodites, $8.4 \%$ for $P$. parvus adults, and $5.0 \%$ for $P$. parvus copepodites.

Discharge mortality of $A$. hongi adults is significantly and positively correlated with water temperature differences between the intake and discharge (Fig. 3, $p=0.01$, adjusted $\left.R^{2}=0.37, d f=12\right)$. No correlations are detected $(p=0.87$, and $p=0.15$, respectively) for $A$. hongi copepodites and P. parvus, of which mortalities were measured less frequently than that of $A$. hongi adults. Mortality difference of $A$. hongi adults between the intake and discharge is significantly and negatively correlated with discharge temperature (Fig. 3, $p=0.01$, adjusted $R^{2}=0.35, d f=12$ ). This provides further support that mortality is higher at lower water temperature.

\section{Thermal Stress Tests in the Laboratory}

Regardless of the starting incubation temperature of each experiment, thermal stress tests in the laboratory show that a temperature increase of $3-4^{\circ} \mathrm{C}$ above the controls generally does not increase copepod mortality, (Fig. 4). At temperature differences of more than $4^{\circ} \mathrm{C}$, however, copepod mortality tends to substantially increase. Egg production rate (EPR) of A. hongi is lower at 9.6 eggs female $\mathrm{e}^{-1} \mathrm{~d}^{-1}$ in February and higher in May at 12.3 eggs female $\mathrm{e}^{-1} \mathrm{~d}^{-1}$. Incubation of the females at $1^{\circ} \mathrm{C}$ incremented water temperatures in each treatment results in an improved EPR in February (Fig. 5, a linear regression, $p=0.02$ ). EPR also increases in May until $14^{\circ} \mathrm{C}$, but tends to stabilize or even decrease at higher temperature treatments (Fig. 5). Variation of EPR appears to be consistent with the abundance distribution of copepods in the area, with peak densities observed generally between 10 and $15^{\circ} \mathrm{C}$ (Fig. 5). 

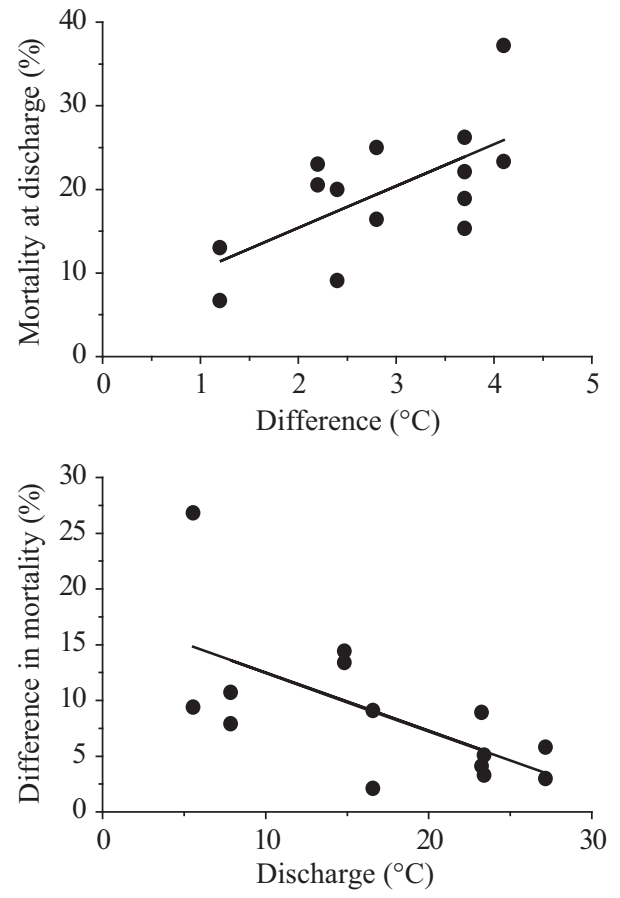

Fig. 3. Acartia hongi: temperature difference between seawater intake (Station 9) and discharge waters (Station 10) vs. mortality in the discharge water (upper panel); discharge water temperature vs. mortality difference between seawater intake and discharge water (lower panel).

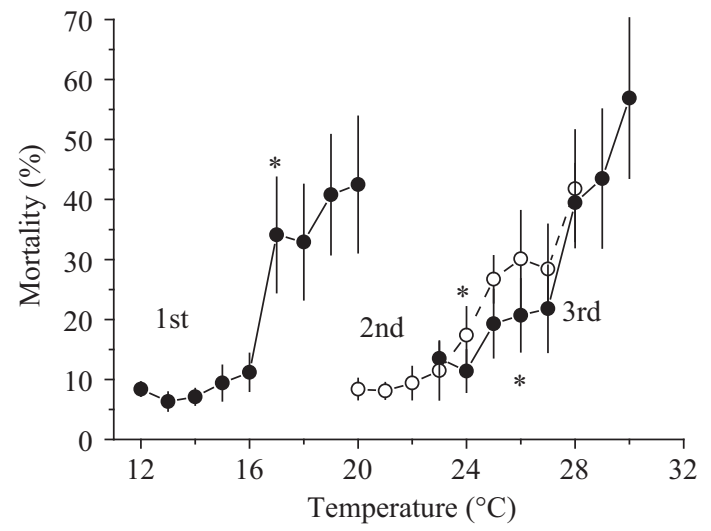

Fig. 4. Acartia hongi: thermal stress expressed as mortality after 72 h incubation at control and various water temperatures incrementally increased by $1^{\circ} \mathrm{C}$ from the control. Asterisks indicate temperature when mortality was significantly higher than that at lower temperatures (Tukey's post-hoc test at $\alpha=0.05$ level), with vertical bars representing $95 \%$ confidence interval.

\section{Biomass Comparisons between Intake and Discharge}

Biomass comparisons of the plankton samples collected at the intake and discharge locations show similar results (Fig. 6). Visual examination of chl $a$ concentration, ciliates, and copepod abundance reveals that they all approximately fall on the 1:1 line, with apparent random distributions of data points around the 1:1 lines. Regression analyses with zero intercepts
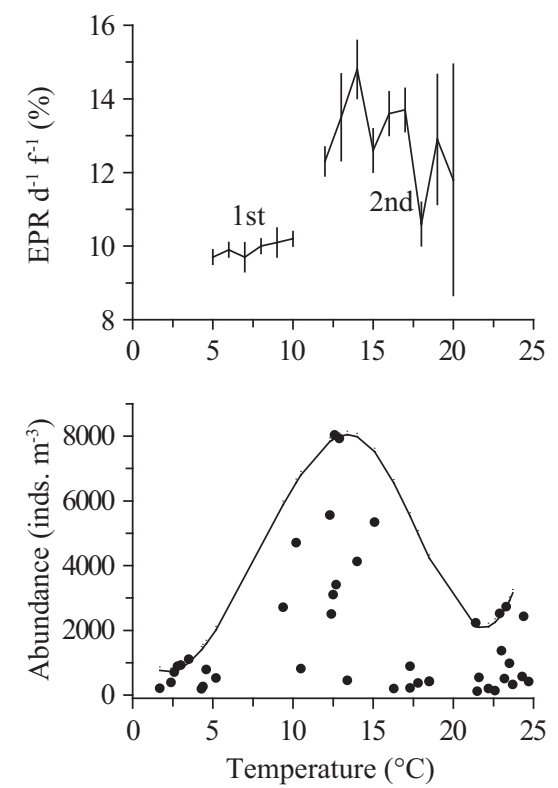

Fig. 5. Acartia hongi: egg production rate (EPR) of females exposed to various water temperatures in two laboratory experiments occurring in February and May (upper panel), and temperature vs. A. hongi abundance relationship, with a splined $95 \%$ quantile regression on the seawater temperature [20].
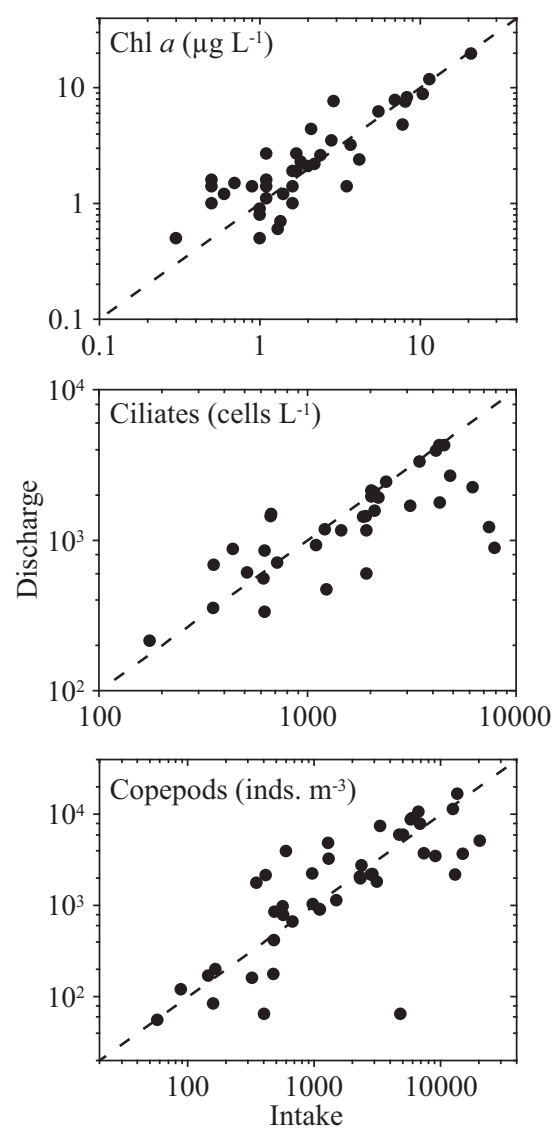

Fig. 6. Intake vs. discharge waters: comparison of chl $a$ concentration, ciliate density, and copepod abundance between the two locations with a 1:1 relationship indicated as a dashed line. 

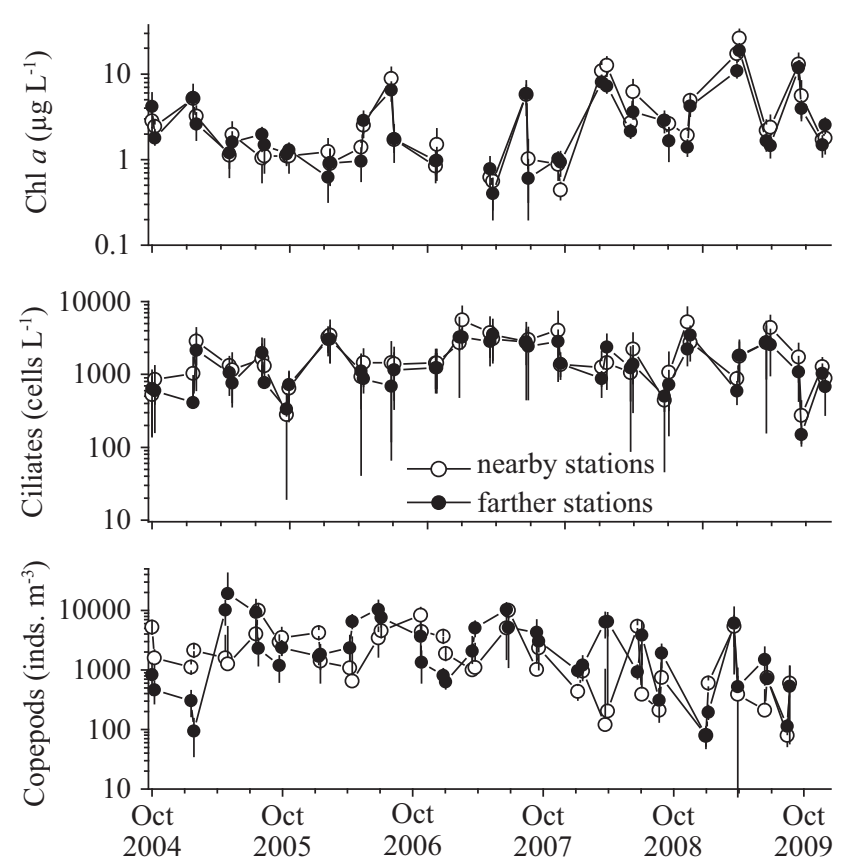

Fig. 7. Temporal changes (mean and $95 \% \mathrm{CL}$ ) over a five-year period of chl $a$ concentration, ciliate density, and copepod abundance at stations (Stations 3, 4, 5, 9, and 10) close to thermal effluents vs. biomass at stations farther from thermal effluent discharge locations (Stations 1, 2, 6, 7, and 8).

also confirm the visual assessments. Regression slopes of both chl $a$ and copepod abundance include a 1 within $95 \%$ confidence limit (0.87 - 1.05, $0.99-1.03$, respectively), with ciliate abundance slightly less than 1 (0.95 - 0.99). When the biomass comparison is expanded spatially beyond the intake and discharge area, chl $a$ concentration, ciliate density, and total copepod abundance at stations in proximity to the power plant show no discernable differences from the values at the stations distant from the power plant that are much less likely be affected by thermal effluents (Fig. 7).

\section{Regional Impacts of Thermal Effluents}

This study further examined the temporal dynamic pattern of the plankton to better understand the environmental conditions that may regulate plankton dynamics in the region. Phytoplankton generally bloomed in early spring (February) in the early years, but summer blooms became apparent in more recent years (Fig. 8). Temporal change (mean $\pm 95 \%$ CL) of chl $a$ concentration over a five-year period shows an increasing trend toward 2009, but is not related to any of the environmental parameters of temperature, salinity, dissolved inorganic nitrogen or phosphate concentration (data not shown). Ciliate density is tightly coupled with suspended particulate matter (SPM) concentration with no apparent time lag (Fig. 9). The change of ciliate abundance in a successive sampling period is significantly and positively related with the change of SPM concentration (Fig. 9, $p<0.01$, adjusted $R^{2}=0.14, d f=$ 39). Ciliate density is not related to the change in chl $a$ con-
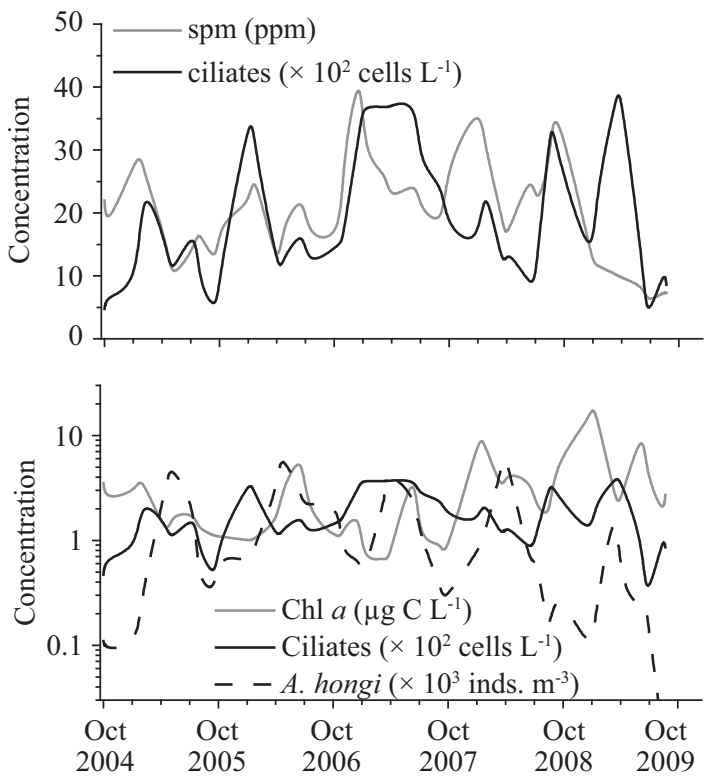

Fig. 8. Successive difference in suspended particulate matter (SPM) concentration vs. successive difference in ciliate abundance. Data shown from the 2005-2009 surveys.

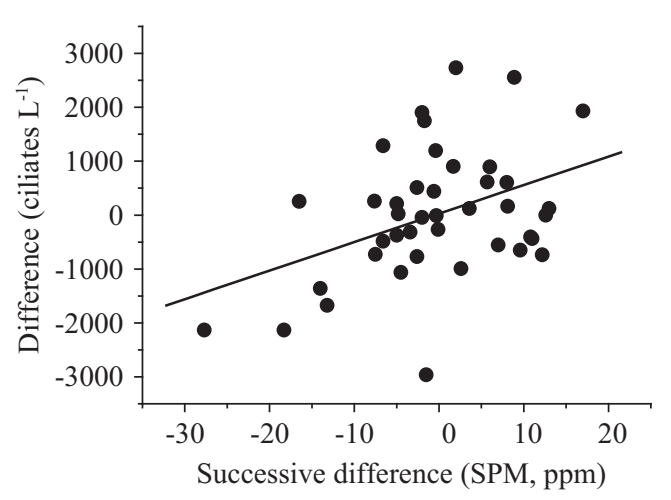

Fig. 9. Successive difference in suspended particulate matter (SPM) concentration vs. successive difference in ciliate abundance. Data shown from the 2005-2009 surveys.

centration. A. hongi abundance, which peaks generally in the winter and spring, closely follows the temporal trend of both chl $a$ concentration and ciliate density, often traces the temporal trend of ciliates more closely than that of chl $a$ concentration, although the pattern became less clear in 2009 (Fig. 8).

\section{DISCUSSION}

\section{Thermal Impacts on Copepods}

The results of copepod mortalities measured in the field studies suggest that thermal shock had a major impact on the entrained copepods in this study. However, the results of the large copepod mortality observed are somewhat unexpected given the small temperature differences $\left(3-4^{\circ} \mathrm{C}\right)$ between the intake and discharge and relatively low water temperature 


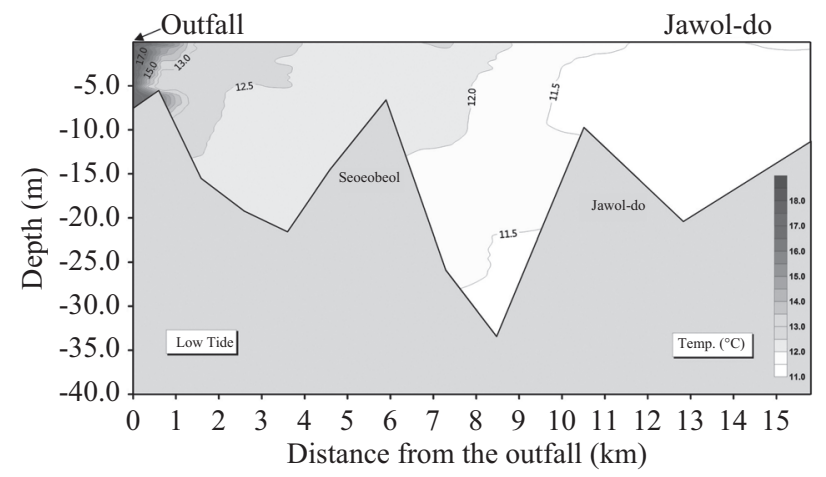

Fig. 10. An example of cross-sectional seawater temperature distribution from thermal discharge location to the south-west. The survey was made during a low tide in May 2010.

$\left(<30^{\circ} \mathrm{C}\right)$ at the discharge even at its warmest. Most studies indicate that acute thermal stress manifests only at large temperature differences (at least $7^{\circ} \mathrm{C}$ ) between intake and discharge [1], and more strongly at higher water temperatures close to the thermal limits of plankton. For instance, plankton with high survival rates can experience sharply reduced survivorship by water temperature increases of as little as $1-2^{\circ} \mathrm{C}$, even after short-term exposure [3, 24]. Organisms in subtropical and tropical regions inhabiting a condition close to their lethal limits can undergo severe stress once entrained in condenser cooling systems [3, 22, 29]. Simulated results of thermal effluents show that the discharge water temperature can rise by as much as $9^{\circ} \mathrm{C}$ in winter and $7^{\circ} \mathrm{C}$ in summer [21]. Field monitoring of seawater temperature shows that temperature difference between the outfall and ambient seawater can be as large as $8-9^{\circ} \mathrm{C}$ (Fig. 10), suggesting that copepods in the discharge that has passed through the cooling condenser can be subjected to thermal shock in a relatively short time period of tidal cycles. Substantial mortality, therefore, can occur if the water temperature difference between the intake and discharge or between the intake and ambient waters becomes $>4-5^{\circ} \mathrm{C}$ for a prolonged period given the relatively small range of temperature tolerance for this copepod (Fig. 4).

\section{Limited Effects of Chlorine on Mortality}

Given the very low concentration $(<0.1 \mathrm{ppm})$ applied in this plant, chlorine would have had very limited impact on copepod mortality. Laboratory tests show that a ten minute exposure of $A$. hongi adults to a combination of $20^{\circ} \mathrm{C}$ and 0.5 ppm of electrolysis-produced $\mathrm{NaOCl}$ expressed as total residual chlorine (TRC), which is smaller than nominal chlorine concentration, results in no significant difference from the controls [15]. Exposure for $1 \mathrm{hr}$ at the same concentration only increases mortality to $5-20 \%$ compared to the controls [15]. The 50\% lethal concentrations for $10 \mathrm{~min}$. and $1 \mathrm{~h} \mathrm{ex-}$ posure are estimated at $2 \mathrm{ppm}$ and $1.5 \mathrm{ppm}$, respectively (Fig. 5 in [15]), much higher than that which $A$. hongi would have been exposed to during the passage of the plant cooling condenser. Other Acartia spp. also show similar levels of toler- ance to chlorine residues [11, 23]. The mortality of Acartia tonsa was recorded as $13.5 \pm 3.9 \%$ on average for TRC between 0.14 and $0.24 \mathrm{ppm}$ [1], with $L C_{50}$ estimated at $1 \mathrm{ppm}$ for Acartia tonsa exposed for $30 \mathrm{~min}$ to the toxicant [13].

However, even at lower concentrations, chlorine can be deleterious when combined with thermal stress. Increased temperature difference between intake and discharge can significantly reduce chlorine concentration for $L C_{50}[3,23,25]$. The $50 \%$ lethal concentration for $A$. omorii at $\Delta T=0^{\circ} \mathrm{C}$ ranges from 0.36 to $1.51 \mathrm{ppm}$ for exposure times of up to 30 minutes. Although temperature spikes during the passage of the condenser may be unrealistic in this study, the $L C_{50}$ concentration for chlorine is reduced by as much as a half at a temperature difference of $11^{\circ} \mathrm{C}$ [23]. Generally, thermal effects on chlorine toxicity become important when the thermal limit of organisms is approached [5]. Chlorination level applied in this power plant may have had more impact on microbes than on metazoans during the passage of condenser [6], which reports 95 to $98 \%$ inhibition of bacterial production at $0.13 \mathrm{ppm}$ of chlorine applied.

\section{Mechanical Stress}

With differential sensitivity among zooplankton taxa to plant passage [24], entrained plankton are also subject to other stresses from mechanical damage (e.g., abrasion and collision) and pressure change. No mechanical damage is reported for $A$. tonsa during the passage of the condenser, but pressure change alone, with $\Delta T=0^{\circ} \mathrm{C}$ and no chlorine applied, increased mortality to approximately $8 \%$ for $A$. tons $a$ as compared to the controls [1]. Tests with a combination of hypochlorite addition and pressure change showed no significantly difference in mortalities from those with hypochlorite addition only [1], suggesting that chlorine was the major stress to zooplankton in the previous study. Although subtle effects are difficult to detect, visual examination of the zooplankton samples collected on the net show few signs of mechanical damage or pressure induced damage such as broken antenna or ruptured prosomes.

\section{Regional Impacts of Thermal Effluents}

The extent to which thermal effluents affect local plankton community varies. Thermal effluents coming out of an outlet containing high temperature seawater generally carry very low microbial biomass and activity [6]. As the thermal plume moves out into coastal waters, the plume is diluted with ambient seawater. Mixing of ambient seawater and thermal effluents plays an important role in determining planktonic biomass $[6,30]$. Some studies have identified reductions in microbial biomass, primary production, and zooplankton biomass up to $200 \mathrm{~m}$ from the discharge of industrial cooling systems [6, 10, 30, 38]. In contrast, other studies have found no detectable effects of cooling water discharge upon plankton abundance beyond the actual discharge point [5, 18]. No detectable reduction in plankton abundance is found between the intake and discharge waters (Fig. 6), even though plankton 
mortality in cooling systems ranges from 3 to $39 \%$ (Fig. 2). If zooplankton sampling at the discharge point had been possible, reduced biomass might have been observed. Yet, the little intake-discharge biomass differences suggest that plankton in the thermal effluents is replenished by the local plankton populations of ambient seawater in this macrotidal region $[3,5$, 18].

\section{Thermal Adaptations}

As indicated in reduced mortality in warm months compared to the higher mortality in cold months (Fig. 3), thermal adaptation appears to play an important role. Copepods adapted to higher temperatures may be better able to withstand a sudden increase of temperature than copepods living in cold water as long as the temperature stays below the critical thermal maxima $[4,16]$. For instance, the $L T_{50}$ (the $50 \%$ lethal temperature) of Calanus sinicus and Labidocera euchaeta, both calanoid copepods, increases with the rise of acclimation temperature for the same exposure time [16]. To tolerate a wide range of thermal stresses [12], some zooplankton can adapt to increased water temperature by shifting thermal limits and reducing respiration. Increased temperature can also stimulate egg production rate of local copepod populations in the discharge area (Fig. 5). This compensates, to some extent, for the increased mortality in winter and spring, but probably not in summer and fall when respiration rate is presumably high and the water temperature is already above the optimal range for egg production for this copepod (Fig. 5).

\section{What Controls Copepod Dynamics}

The tight coupling between SPM and ciliates, and the close tracing of ciliate abundance by A. hongi, suggest that the zooplankton community in this region is partly supported by a food web fueled by SPM input. Labile fractions of SPM serve as sources of dissolved and particulate organic carbon for microorganisms, including ciliates [31]. As has been demonstrated in other species of Acartia genus, and often referred to as trophic upgrading $[2,17,27,34]$, ciliates are an important food diet for $A$. hongi $[36,37]$. Weight specific egg production rate of $A$. hongi asymptotically approaches above $>10 \mu \mathrm{g}$ chl $a$ [36], suggesting that $A$. hongi may be chronically food limited in this region during most of the year due to light limitation from relatively high SPM concentrations (6-45 ppm, Fig. 8). A. hongi is flexible in its feeding, but preferentially feeds on ciliates over small phytoplankton [36]. Weightspecific egg production rate of $A$. hongi is higher with ciliates than chl $a$ alone [36], consistent with the temporal dynamic pattern of the plankton community (Fig. 8).

\section{CONCLUSION}

Thermal impact appears to be a major factor of copepod mortality in the cooling processes but, as local populations are quickly replenished via tidal mixing processes from adjacent natural populations, there is limited thermal impact on local populations. Copepod populations appear to be supported by microzooplankton fueled by organic matter input.

\section{ACKNOWLEDGMENTS}

This research was funded by the Korea South-East Power Co.'s project "Post-environmental impact assessment of YoungHeung Power Plant". We thank Young-Soo Park at KSEP for assistance with the project, and Min-Ho Soh for his assistance with laboratory work for zooplankton samples. We also thank two anonymous reviewers for their helpful comments on an earlier version of this manuscript.

\section{REFERENCES}

1. Bamber, R. N. and Seaby, R. M. H., "The effects of power station entrainment passage on three species of marine planktonic crustacean, Acartia tonsa (Copepoda), Crangon crangon (Decapoda) and Homarus gammarus (Decapoda)," Marine Environmental Research, Vol. 57, pp. 281-294 (2004).

2. Bollens, G. C. R. and Penry, D. L., "Feeding dynamics of Acartia spp. copepods in a large, temperate estuary (San Francisco Bay, CA)," Marine Ecology Progress Series, Vol. 257, pp. 139-158 (2003).

3. Capuzzo, J., "Impact of power-plant discharges on marine zooplankton: A review of thermal, mechanical and biocidal effects," Helgoland Marine Research, Vol. 33, pp. $422-432$ (1980).

4. Carpenter, E. J., Peck, B. B., and Anderson, S. J., "Cooling water chlorination and productivity of entrained phytoplankton," Marine Biology, Vol. 16, pp. 37-40 (1969).

5. Carpenter, E. J., Peck, B. B., and Anderson, S. J., "Survival of copepods passing through a nuclear power station on northeastern Long Island Sound, USA," Marine Biology, Vol. 24, pp. 49-55 (1974).

6. Choi, D. H., Park, J. S., Hwang, C. Y., Huh, S. H., and Cho, B. C., "Effects of thermal effluents from a power station on bacteria and heterotrophic nanoflagellates in coastal waters," Marine Ecology and Progress Series, Vol. 229, pp. 1-10 (2002).

7. Dressel, D., Heinle, D., and Grote, M., "Vital staining to sort dead and live copepods," Chesapeake Science, Vol. 13, pp. 156-159 (1972).

8 Evans, M. S., Warren, G. J., and Page, D. I., "The effects of power plant passage on zooplankton mortalities: Eight years of study at the Donald C. Cook nuclear plant," Water Research, Vol. 20, pp. 725-734 (1986).

9. Fleming, J. and Coughlan, J., "Preservation of vitally stained zooplankton for live/dead sorting," Estuaries and Coasts, Vol. 1, pp. 135-137 (1978).

10. Fox, J. and Moyer, M., "Effect of power plant chlorination on estuarine productivity," Chesapeake Science, Vol. 16, pp. 66-68 (1975).

11. Gentile, J. H., Cardin, J., Johnson, M., and Sosnowski, S., Power Plants, Chlorine, and Estuaries, Environmental Protection Agency, USA (1976).

12. González, J. G., "Critical thermal maxima and upper lethal temperatures for the calanoid copepods Acartia tonsa and A. clausi," Marine Biology, Vol. 27, pp. 219-223 (1974).

13. Heinle, D. and Beaven, M., "Effects of chlorine on the copepod Acartia tonsa," Chesapeake Science, Vol. 18, p. 140 (1977).

14. Hoffmeyer, M. S., Biancalana, F., and Berasategui, A., "Impact of a power plant cooling system on copepod and meroplankton survival (Bahía Blanca estuary, Argentina)," Iheringia Série Zoologia, Vol. 95, pp. 311-318 (2005).

15. Jeong, $\mathrm{H}$., " $\mathrm{NaOCl}$ produced by electrolysis of natural seawater as a potential method to control marine red-tide dinoflagellates," Phycologia, Vol. 41, pp. 643-656 (2002).

16. Jiang, Z., Zeng, J., Chen, Q., Huang, Y., Xu, X., Liao, Y., Shou, L., and Liu, J., "Tolerance of copepods to short-term thermal stress caused by coastal power stations," Journal of Thermal Biology, Vol. 33, pp. 419-423 (2008). 
17. Jonsson, P. and Tiselius, P., "Feeding behaviour, prey detection and capture efficiency of the copepod Acartia tonsa feeding on planktonic ciliates," Marine Ecology and Progress Series, Vol. 60, pp. 35-44 (1990).

18. Jordan, R. A., Martin, P. G., and Sutton, C. E., "Selective effects of phytoplankton entrainment at the Surry power plant, James River, Virginia," Hydrobiologia, Vol. 106, pp. 253-261 (1983).

19. Kartasheva, N., Fomin, D. V., Popov, A. V., Kuchkina, M. A., and Minin, D. V., "Impact assessment of nuclear and thermal power plants on zooplankton in cooling ponds," Moscow University Biological Sciences Bulletin, Vol. 63, pp. 118-122 (2008).

20. Koenker, R., Quantile Regression, Cambridge University Press, London (2005).

21. Korea South-East Power Co., Environmental Impact Assessment of the Construction of the Units 3 and 4 of the Young-Heung Power Plants, p. $718(2005)$

22. Langford, T. E. L., Ecological Effects of Thermal Discharges, Elsevier Applied Science Publishers, London (1990).

23. Marumo, K., Sato, E., and Ishikawa, Y., "Experimental study on acute effects of the combined exposure to temperature increase and chlorination upon the marine copepod Acartia omorii," Marine Biology, Vol. 114, pp. 235-240 (1992).

24. Mayhew, D. A., "A comparative review of entrainment survival studies at power plants in estuarine environments," Environmental Science \& Policy, Vol. 3, pp. 295-301 (2000).

25. McLean, R. I., "Chlorine and temperature stress on estuarine invertebrates," Water Pollution Control Federation, Vol. 45, pp. 837-841 (1973).

26. Morgan, R. and Stross, R., "Destruction of phytoplankton in the cooling water supply of a steam electric station," Chesapeake Science, Vol. 10, pp. 165-171 (1969).

27. Ngurah, N. W. and Rassoulzadegan, F., "Selective feeding of Acartia clausi and Centropages typicus on microzooplankton," Marine Ecology Progress Series, Vol. 53, pp. 37-45 (1989).

28. Parsons, T. R., Maita, Y., and Lalli, C. M., A Manual of Biological and Chemical Methods for Seawater Analysis, Pergamon Press, New York
(1984).

29. Poornima, E. H., "Impact of thermal discharge from a tropical coastal power plant on phytoplankton," Journal of Thermal Biology, Vol. 30, pp. 307-316 (2005).

30. Shiah, F.-K., Wu, T. S., Li, K. Y., Kao, S. J., Tseng, Y. F., Chung, J. L., and Jan, S., "Thermal effects on heterotrophic processes in a coastal ecosystem adjacent to a nuclear power plant," Marine Ecology Progress Series, Vol. 309, pp. 55-65 (2006).

31. Smith, D. C., Simon, M., Alldredge, A. L., and Azam, F., "Intense hydrolytic enzyme activity on marine aggregates and implications for rapid particle dissolution," Nature, Vol. 359, pp. 139-142 (1992).

32. Takesue, K. and Tsuruta, A., "The thermal effects of the cooling system of a thermal power plant on photosynthesis of marine phytoplankton," Journal of Oceanography, Vol. 34, pp. 295-302 (1978).

33. Tang, K. W., Freund, C. S., and Schweitzer, C. L., "Occurrence of copepod carcasses in the lower Chesapeake Bay and their decomposition by ambient microbes," Estuarine, Coastal and Shelf Science, Vol. 68, pp. 499-508 (2006)

34. Tanga, K. W. and Taalb, M., "Trophic modification of food quality by heterotrophic protists: species-specific effects on copepod egg production and egg hatching," Journal of Experimental Marine Biology and Ecology, Vol. 318, pp. 85-98 (2005).

35. Taylor, C. J. L., "The effects of biological fouling control at coastal and estuarine power stations," Marine Pollution Bulletin, Vol. 53, pp. 30-48 (2006).

36. Yang, E. J. and Choi, J. K., "Ingestion on planktonic ciliates by copepod Acartia hongi: a laboratory study," Ocean and Polar Research, Vol. 31, pp. 265-276 (2009).

37. Youn, S. H. and Choi, J. K., "Egg production of the copepod Acartia hongi in Kyeonggi Bay, Korea," Journal of Marine Systems, Vol. 67, pp. 217-224 (2007).

38. Youngbluth, M. J., "Zooplankton populations in a polluted, tropical embayment," Estuarine and Coastal Marine Science, Vol. 4, pp. 481-496 (1976). 